\title{
OPEN MONGOLIA AND MONGOL-RUSSIAN RELATIONS
}

\section{Ts.Batbayar}

\section{Evolution of Mongolia's role between Russia and China}

The 1990s brought significant changes to Mongolia itself, and to its relations with the outside world. The Mongolian People's Republic, which was rightfully regarded as the Soviet closest ally in Asia during Cold War era, terminated its existence after almost 70 years of its history (1924-1992). The new, democratic and open Mongolia was born in January 1992.

Up to 1946, the Mongolian People's Republic was acknowledged only by its protector the Soviet Union. Its international recognition came with the end of World War 2 when great powers arranged so-called Yalta post war system. The Soviet leader Stalin insisted in the preservation of its status-quo and in its eventual recognition by China as a part of Yalta arrangement which made possible Soviet entrance into war against Japan. After face-saving plebiscite conducted in the MPR in October 1945 the Kuomintang China had to recognize grudgingly the Mongolian People's Republic in January 1946.

The birth of the communist China (October, 1949) was the most profound event for Mongolian People's Republic, in the 1950s. Ulaanbaatar recognized Beijing on October 6, 1949, immediately after the founding of the People's Republic of China. The independent status of the MPR was secured when a SinoSoviet joint communiquй was issued in Moscow in early 1950 following Mao Zedong trip to the Soviet Union. For a brief period, the MPR enjoyed its role as an important bridge in a larger Soviet-Chinese cooperative alliance.

By mid 1960s, the Sino-Soviet split left no choice for Mongolian leadership. Ulaanbaatar took the Soviet position on every other issue which divided Moscow and Beijing and agreed to conclude 1966 bilateral treaty with Moscow. The twenty-year Treaty included unpublished defense-related agreements and started a massive buildup in Mongolia of Soviet troops and missile bases. The Mongolian People's Republic became a frontline of Soviet defense against China for about twenty years. Relations with China remained as the foremost concern for the MPR leadership. Mongolia's leader Tsedenbal maintained his "cold war" with China. Even Mao's death in 1976 did not change his hostility and suspicions toward China. Mongolia doubled the size of its army in response to a request made by Soviet defense minister Ustinov to Tsedenbal while the latter 
visited Moscow in 1978. Soviet armed forces in Mongolia reached their peak of 120,000 men in 1979.

There was another important reason why Tsedenbal was so anti-China oriented. Tsedenbal had a very powerful "China card" in his pocket, and he did not hesitate to play it. Each twist and turn in Sino-Soviet relations was used as an excellent argument to ask the Soviet Government to render more economic assistance toward Mongolia. Because of the MPR's geopolitical importance Moscow agreed to unconditionally underwrite Mongolia's two five-year plans for 1971-75 and 1976-1980. ${ }^{1}$

During the Cultural Revolution, the Chinese Red Guards charged Tsedenbal with allowing Moscow to maintain Mongolia as a "neocolonial 'dependency. Tsedenbal used this kind of allegations as a great excuse to acquire more and more aid from Moscow. For that reason, the Soviet Government paid 600 million rubles to build a huge copper plant, called Erdenet, between 1973 and 1981 in northern Mongolia, not far from Soviet border. This giant joint venture to process copper and molybdenum concentrate was the biggest Soviet economic project ever attempted in Mongolia, and became the MPR's largest foreign currency earning enterprise.

By the beginning of 1980s major changes occurred in Sino-Soviet relations. With Deng Xiaoping's reform underway in rural China and Brezhnev's death in Moscow, Sino-Soviet relations began to improve eventually. However, Tsedenbal failed to understand the new developments in Mongolia's external environment and continued to stage anti-Chinese campaigns in the hope of getting more favors from Moscow. New leaders of the Kremlin, including Gorbachev, not pleased by old tactics of Tsedenbal, asked the KGB to prove Tsedenbal's "critical health condition" and have him removed from the top position. Tsedenbal was ousted from office in August 1984.

Gorbachev's Vladivostok initiative, including his offer to remove some Soviet troops from Mongolia, was a surprise event for Ulaanbaatar which no longer could enjoy its almost twenty year safe isolation from China. The same thing was true for Mongolia's relations with major western countries. With the arrival of Shevardnadze to the Kremlin, Ulaanbaatar was allowed to enter into direct negotiations with Washington. Shevardnadze's January 1986 visit to Ulaanbaatar, gave a "green light" to that issue and Mongolia established diplomatic relations with the US in January $1987 .^{2}$

Encouraged by "new thinking" in Moscow Ulaanbaatar exchanged visits with Beijing on a vice-foreign minister level and entered into diplomatic relations 
with the Republic of Korea before than Moscow did the same thing. Mongolian foreign minister visited Japan in 1987 and in August 1989 Ulaanbaatar suggested the creation of a "mechanism of political dialogue" in Northeast Asia to discuss non-political issues, aimed at developing effective and mutually beneficial cooperation in the fields of economy, science and technology, culture and education, ecology and humanitarian links.

The breakthrough in Mongolia's relations with its southern neighbor, China, came in 1990-1991. P. Ochirbat, Mongolia's newly elected President, went first to Beijing, not to Moscow as usual, in May 1990 which had paved the way for new kind of relations between Mongolia and China. With the announced schedule of Soviet troops withdrawal from Mongolia due to be completed by early 1992, the Chinese leaders had no reason to refuse in high-level return visit. Yang Shangkun, the chairman of the PRC, paid an official four-day visit to Ulaanbaatar, during which an intergovernmental agreement on Mongolia's access to the sea and transit transportation across Chinese territory with the use of Tianjin port was signed. Chinese Premier Li Peng visited Ulaanbaatar in April 1994 and signed the new bilateral treaty between two countries.

In February, 1991, then Prime Minister D. Byambasuren paid a visit to Moscow and met the chairman of the Council of Ministers of the Russian Federated Soviet Socialist Republic, I. S. Slave. The highlight of his visit was the Declaration on Friendship and Good-Neighborly Cooperation concluded between Mongolia and Russia. Seventy years after the agreement of 5 November 1921, Mongolia and Russia reaffirmed the basis of their relations as one between equal sovereign states and summarized the new trends on bilateral cooperation, based on generally accepted principles of good-neighborly relations.

\section{The period of adjustment in Mongol-Russian relations}

In 1990 Mongolia held the first free elections in its 80 years of modern history and has taken important steps toward a multiparty, pluralistic and democratic society. Perestroika in the Soviet Union and democratic changes in Eastern Europe helped to create a favorable external environment. The political influence of the Soviet Union in Mongolia diminished substantially by late 1980s as the Soviet government had to turn more toward its internal problems than toward its allies.

It is interesting to note that the first priority for young democrats was how to get rid of Soviet dominance rather than how to introduce democracy. The specifics of the Mongolian transition were brought about by its political and 
economic status as the closest Soviet satellite. The uninterrupted rule of the Mongolian People's Revolutionary Party (MPRP) was seen as a political arrangement for perpetuating the Mongolia's inferior political status, and the removal of the MPRP's monopoly of power was seen as an act of political decolonization.

The resignation of the MPRP Politburo in March 1990 led to the Constitutional amendments that made possible the first free elections held in July 1990. The standing legislature, Baga Hural, where the MRPR controlled about 60 percent of seats and young democrats the remaining 40 percent, became the main parliamentary mechanism for the Mongolia's smooth transition. Both MPRP majority and democratic minority in the Baga Hural realized the urgent need for a new constitution which would legitimize the emerging political and economic institutions.

The new political elite were also aware of dramatically changing international situation. To the south, China was pursuing its politically rigid strategy of "building socialism with Chinese characteristics", and to the north, Russia had been thrown into a political, economic, constitutional, and federal turmoil. The 1992 new constitution established a domestic framework for a continued open foreign policy and a new international orientation. ${ }^{3}$

The formation of the Commonwealth of Independent States in December 1991 was greeted with cautious optimism by the Mongolian Government. Mongolia quickly recognized the independence of the three Baltic States and established diplomatic relations with them. Recognition of the republics in the Commonwealth of Independent States by Mongolia followed soon.

Throughout 1992, scheduling a summit meeting and normalization of trade flows were the two top priorities pf Mongolian diplomacy toward Russia. In February, during a working visit to Moscow, Prime Minister Byambasuren facilitated the shipment of badly needed Russian oil but failed to meet the Russian President. Russia sent a new ambassador - a 39-year old China expert, to Ulaanbaatar in April. The question of a summit meeting was again raised before President Yeltsin's May visit to the Siberian regions neighboring Mongolia. Russian side put forth the signing of a new treaty between the two countries as a precondition for a summit meeting.

With the completion of the Russian troop withdrawal on September 15, 1992, Mongolia declared its intention of pursuing a course of balanced relations with Russia as well as with China. Mongolia's new Constitution legalized the future policy of not allowing foreign troops to enter, be stationed in or pass 
across its territory unless a relevant Mongolian legislation was adopted. Both Russia and China welcomed Mongolia's "neutral' policy and committed themselves to respect Mongolia's policy of not letting its territory be used against any neighboring state.

The top priority in Mongolia's next diplomacy was to fill the vacuum in its foreign relations created by the Soviet Union's disintegration, and revive full political and economic relations with the newly independent republics of the former USSR - first and foremost - the Russian Federation. President Ochirbat went to Moscow in January 1993 for a long-awaited summit meeting with President Yeltsin, which produced tangible results. A number of important documents including a Joint statement on Stalinist purges of 1930s in Mongolia and an agreement on transfer of former Soviet army property and buildings to Mongolian side were signed between two sides.

The signing of a new bilateral treaty, which excluded the mutual military assistance clause of the previous (1966) treaty, was the highlight of the visit. Russia recognized Mongolia's nuclear free zone status and obliged to respect Mongolia's independent status. Article 4 of the treaty states that "the parties shall not enter into any military-political bloc, directed against each other and are committed not to conclude with third parties any treaties and agreements contradicting the interests of sovereignty and independence of the other party".

Although the two presidents exchanged opinions in a candid manner, they failed to resolve the thorny debt problem which clouded the bilateral relations since 1990. Mongolia's debt to the former USSR made mostly between 1970 and 1990 was surfaced as the most controversial issue between Mongolia and Russia. The two sides disagree on USD value of the original 10 billion transferable ruble debts. Some journalists and individuals in Mongolia even argued that Mongolia owes Russia nothing at all.

However, two sides agreed to set up an intergovernmental commission to discuss the whole complex of debt related issues. In these discussions Mongolian side pointed out the particular historical circumstances in which debt was accumulated which included the artificially low price of Mongolian livestock products exports to Russia. The two sides could narrow their differences on the estimation of present value of total debt and agreed to consider the factors which caused the huge trade imbalance in favor of the USSR. Moreover, Russian Deputy Prime Minister Oleg Davydov during his visit in November 1995, expressed Russian government's readiness to write off a significant part of total debt if a compromise will be reached between two parties. ${ }^{5}$ 


\section{Mongolia's changing trade with Russia}

The Mongolian People's Republic used to receive substantial aid from the former Soviet Union equivalent to about 30 percent of its GDP. Since 1962, it enjoyed a "captive" market in the former Council of Mutual Economic Assistance (CMEA) countries for many of its products. Prior to 1990, over 90 percent of foreign trade was conducted with former Soviet Union and other CMEA countries on the basis of so-called transferable rubles.

The disintegration of the USSR and the breakdown of trade with the CMEA affected badly Mongolia's economy. The import of petroleum from Russia has become a question of survival for Mongolia. In the first four months of 1992, Mongolia imported only 21 percent of the gasoline it needed to function normally. By early June 1992, two countries reached a number of agreements including a projected trade volume of US $\$ 400$ million in 1992, making payments in both hard and national currencies, and the required supply by Russia of 800,000 tons of oil. ${ }^{6}$

Both domestic and international trade regime has been effectively liberalized since 1990. Former state-owned foreign trade companies ceased to operate and both private and public enterprises have the right to conduct foreign trade freely. With the exchange rate liberalization in May 1993, export licensing which was practiced during 1990-1993 was formally abolished except for live animals export.

The initial period of foreign trade disruption, especially import contraction was over by 1993. The big rise in country's import is registered since 1994 . According to the latest statistics of the government, Mongolia's import was US\$ 443.4 million and export US\$ 418 million in 1995. It can be explained by somewhat lower world market price of Mongolia's traditional export items including copper and raw cashmere. These two export items still dominate. Mongolia's export with copper making almost 50 percent, with cashmere making about 20 percent of total export.

The most notable change is in broad trade diversification, both in terms of the destination of exports and the sources of imports. Geographical location of foreign trade was diversified. Prior to 1990, over 90 percent of foreign trade was conducted with the former Soviet Union and Eastern Europe. By 1995, 54.1 percent of export went to neighboring countries and East Asia, 24.5 percent to Western Europe, and remaining 15.2 percent to Eastern Europe.

Trade with neighboring China and some other East Asian countries increased rapidly. For example, trade with China increased from less than 2 percent 
of the Mongolia's total in 1989 to about 24 percent in 1993. Although its volume decreased to 15.5 percent in 1994, 12.5 percent of Mongolia's total in 1995, potential for growth remains. Mongolia's export to China mostly consists of animal skins and hides ( 30 percent), cashmere and wool (38 percent), and copper (17 percent). Booming border trade between Mongolia and Chinese Inner Mongolia, somehow declined since 1994, contributed to this remarkable growth.

Trade with the major traditional partner Russia is undergoing big adjustment. Volume of trade with Russia and former CMEA countries declined from almost 89 percent in 1989 to about 56 percent in 1993. Mongolia usually sells most of its copper to Russia and buys all its petroleum also from Russia. Mongolia is also still dependent on some crucial spare parts imports from Russia for its power plants. Although Mongolia started to receive hard currency for its copper, it had to pay world prices for badly needed fuel and petroleum products. For 1995, copper accounted 73.5 percent of Mongolia's export to Russia, while petroleum products accounted 21.4 percent of its import from Russia. Barter trade made about 35 percent of total two-way trade because of hard currency shortage both sides claim for.

According to foreign trade statistics of 1997, most of Mongolia's foreign trade was conducted with neighboring countries, including Russia, China, and Kazakhstan. Most of Mongolia's imports still come from Russia (36.2\%), next from China (14.3\%), and Japan (7.5\%). Similarly, most of Mongolia's exports went to China (21.7\%) and Russia (9.6\%) with Switzerland as the first export destination $(31.5 \%)^{7}$

\section{Conclusion}

The breakdown of the former Soviet Union left Mongolia virtually in a great power vacuum. That vacuum - political, economic as well as ideological has produced at least three major results. First, for the first time in eighty years it allowed Mongolia to pursue open and de facto independent foreign policy, aimed at protecting its genuine national interests, enhancing ties with the United States, Japan and other democracies. Second, Mongolia's business links with Russia declined dramatically and those with China, virtually stagnant for decades, increased faster than with any other country.

This dramatic switch led to some speculation that Mongolia might turn to China for protection, but that has not happened. Instead, once democracy and a market economy were proclaimed as Mongolia's paramount goals, the country declared its intention of pursuing a course of somewhat balanced relations with 
Russia as well as with China. A third major result was that Mongolia became a full-fledged member of the Non-Aligned

Movement, something the Soviet Union would never have permitted because it would have eroded the solidarity of the socialist bloc.

Russian Foreign Minister Primakov's - the first ever visit of Russian Foreign Minister since 1921 - visit to Ulaanbaatar in November 1996 opened the opportunity for a fresh start in Mongol-Russian relations. Remake reassured the Mongolia side that Russia will consider the historical circumstances in which Mongolia's debt was accumulated and will not put pressure on Mongolia to pay immediately; payments can start after 2000 when a mutually acceptable solution will be reached.

Primakov's visit clearly reflected a rather new active attitude of the Kremlin toward Mongolia than it was under Kozyrev's Foreign Minister Years. Even though old stereotypes die hard, new realities of Mongolia make to think Moscow twice about its assets in Mongolia. Historically, during the past eighty years Russian governments, be they Tsarist or Soviet, have always thought to strengthen their position in Mongolia, and it would be naive to think that Russia would voluntarily abandon this century-old policy. Economically, during the Soviet period Mongolia became an important supplier of livestock materials and mining, and with Soviet assistance hundreds of enterprises, including power stations and modern housing, were built. Still, Russia's economic presence is enormous, including such large joint ventures, as Erdenet copper mining, MonRostsvetmet fluorspar mining, and Ulaanbaatar Railway Company.

In cultural terms, most members of the Mongolian elite graduated from Soviet universities, and Russian is still the most widely spoken foreign language. In 1995, by Russian Presidential decree the number of Mongolian students enrolled in Russian universities under Russian government scholarships was increased from 20 to 80 each year.

Finally, the political and military-strategic factors still remain though they have diminished in importance. Anatoly Arbatov of the Institute of World Economy and International Relations, a well-known Moscow think tank, warned: "The neutrality and sovereignty of Mongolia will represent a considerable security element in Asia, given China's geostrategic position which is projected toward the Russian Tran Caucasus, Kazakhstan, and Kyrgystan. Hi case of a Chinese dominant position in Mongolia, Russian defense needs in this region would triple and communications with the Far East would become more vulnerable". ${ }^{8}$ this kind of thinking seems still strong among Russian security analysts and military circles. 


\section{FOOTNOTES}

1 Ts. Batbayar, Modern Mongolia: A concise history, Ulaanbaatar, 1996, pp. 73-89.

2 Mongolia closely coordinated its foreign policy with the $<$; Soviet Union. Mongolian Ministry of Foreign Affairs received up to half a million USD from the former Soviet Union as a subsidy each year. During Gromyko's time as Soviet foreign minister, Moscow's control was strict and Mongolia was not permitted to establish diplomatic relations with the USA.

3 H.Hulan, Mongolia's New Constitutional Regime: Institutional Tensions and Political Consequences,-The Mongolian Journal of International Affairs, No 3, p. 44.

4 Ardvn Erkh, 23 January 1993.

5 According to Mongolian press reports, Davydov expressed Russia's readiness to write off 80 percent of Mongolia's debt and asked Mongolian side to pay US $\$ 2$ billion as the remaining part of debt converted into USD by the rate 1:1. Mongolian side refused to accept that offer as unfair and asked Russian side to Write off $95 \%$ of total debt and make the rate of conversion of transferable ruble into USD more flexible.

6 Ts. Batbayr, Mongolia in 1992: Back to One-party rule - Asian Survey, Vol. XXXIII, No 1, Jan 1993, pp. 61-66.

7 Ardyn Erkh, 17 January 1998

8 MEMOS, August-September 1994 